\title{
Effect of Amphetamine on Adult Male and Female Rats Prenatally Exposed to Methamphetamine
}

\author{
Romana Šlamberová, Eva Macúchová, Kateryna Nohejlová, \\ Andrea Štofková, Jana Jurčovičová \\ Department of Normal, Pathological and Clinical Physiology, Third Faculty \\ of Medicine, Charles University in Prague, Prague, Czech Republic \\ Received February 27, 2014; Accepted April 4, 2014.
}

Key words: Prenatal drug exposure - Methamphetamine - Amphetamine Open field - Conditioned place preference - Morris water maze - Locomotion Drug-seeking behaviour - Spatial memory - Corticosterone

Abstract: The aim of the present study was to examine the cross-sensitization induced by prenatal methamphetamine (MA) exposure to adult amphetamine (AMP) treatment in male and female rats. Rat mothers received a daily injection of MA $(5 \mathrm{mg} / \mathrm{kg})$ or saline throughout the gestation period. Adult male and female offspring (prenatally MA- or saline-exposed) were administered with AMP $(5 \mathrm{mg} / \mathrm{kg})$ or saline $(1 \mathrm{ml} / \mathrm{kg})$ in adulthood. Behaviour in unknown environment was examined in open field test (Laboras), active drug-seeking behaviour in conditioned place preference test (CPP), spatial memory in the Morris water maze (MWM), and levels of corticosterone (CORT) were analyzed by enzyme immunoassay (EIA). Our data demonstrate that in Laboras test, AMP treatment in adulthood increased general locomotion (time and distance travelled) regardless of the prenatal exposure and sex, while AMP increased exploratory activity (rearing) only in prenatally MA-exposed animals. AMP induced sensitization only in male rats, but not in females when tested drug-seeking behaviour in the CPP test. In the spatial memory MWM test, AMP worsened the performance only in

This study was supported by grant \# GA P303/10/0580 from Grant Agency of the Czech Republic, grant \# NT14484 from Internal Grant Agency from Ministry of Health of the Czech Republic, project \# PRVOUK P34, GAUK 545212 and project \# 260045/ SVV/2014 from Charles University in Prague, \# CSM7/CRP/2014 from Ministry of Education, Youth and Sports of the Czech Republic.

Mailing Address: Prof. Romana Šlamberová, MD., PhD., Department of Normal, Pathological and Clinical Physiology, Third Faculty of Medicine, Charles University in Prague, Ke Karlovu 4, 12000 Prague 2, Czech Republic; Phone: + 420224902 713; Fax: + 420224902 750; e-mail: rslamber@If3.cuni.cz 
females, but not in males. On the other hand, males swam faster after chronic AMP treatment regardless of the prenatal drug exposure. EIA analysis of CORT levels demonstrated higher level in females in all measurement settings. In males, prenatal MA exposure and chronic adult AMP treatment decreased CORT levels. Thus, our data demonstrated that adult AMP treatment affects behaviour of adult rats, their spatial memory and stress response in sex-specific manner. The effect is also influenced by prenatal drug exposure.

\section{Introduction}

The abuse of drugs by women during pregnancy is raising issue of recent years. Since psychoactive drugs can easily cross blood-brain barrier (one of the most impervious barriers of the body), the placental barrier could be passed even easier (Kitaichi et al., 2003). In addition, many drugs can pass into a nursing mother's breast milk and expose a developing infant to drugs even postnatally (Won et al., 2001). Psychostimulants as representatives of the "hard" drugs abused during pregnancy is a risk to the foetus in any case, although the mechanism of action of drugs on the foetus has not been fully elucidated. It should be noted that clinical studies are usually restricted to statistical comparisons because scientific research in humans is very limited due to ethical reasons. And even if a sufficiently large group data collected during early postnatal period, it is not practically possible to maintain this large study group of dependent children until their maturity period. Therefore, experimental studies using animal models are necessary.

Statistical surveys from last few years (Polanecký et al., 1996; Šejda et al., 1998) have demonstrated that methamphetamine (MA) is the most frequently abused illicit drug in the Czech Republic. In recent years, MA, is becoming more "popular street drug" also in other countries because of its relatively simple production process and low price compared to cocaine or heroin (Marwick, 2000). MA is a highly addictive psychostimulant with a great potential for abuse. Because it metabolizes slowly, a MA high lasts for a long period (for 8 to 24 hours) (Won et al., 2001). Women, especially during pregnancy, take MA because it decreases appetite and therefore, helps them to control weight, while increasing energy. Statistics show that only $17 \%$ women abusers in the USA were primary MA users, but 38\% had used it during pregnancy (Marwick, 2000).

Experimental subcutaneous administration of MA in dose of $5 \mathrm{mg} / \mathrm{kg}$ to pregnant laboratory mice or rats leads to foetus brain drug concentrations corresponding to the values of drug observed in the foetuses to the drug-dependent mothers (Martin et al., 1976; Cho et al., 1991; Acuff-Smith et al., 1996). This dose therefore serves as an experimental model of drug exposure in utero for determination of the potential risks in humans. Our previous studies demonstrated that administration of MA during pregnancy attenuates maternal behaviour of rat mothers (Šlamberová et al., 2005) and impairs postnatal development of their pups (Šlamberová et al., 2006). Further, we found that prenatal MA exposure 
with respect of adult MA challenge affects behaviour in unknown environment (Schutová et al., 2013), learning abilities tested in Morris water maze (Schutová et al., 2008; Macúchová et al., 2013), anxiety-like behaviour in elevated plus-maze and in the open field (Schutová et al., 2009b), pain sensitivity tested in plantar tests (Yamamotová and Šlamberová, 2012) and seizure susceptibility in adult male and female rats (Šlamberová et al., 2009; Bernášková et al., 2011; Matějovská et al., 2014). Thus, these results suggest that prenatal MA exposure may induce long-term effects that influence the sensitivity to the same drug in adulthood.

Because there are studies showing that abuse of one drug may increase sensitivity to another drug, which is called cross-sensitization (Bartoletti et al., 1985; He and Grasing, 2004; Valvassori et al., 2007), we were interested whether prenatal MA exposure will induce long-term cross-sensitization as well. Studies of Malanga and Kosofsky (2003) showed that rodents exposed to various drugs abused in utero, become sensitized in adulthood to the rewarding effects of other drugs. For example they respond to lower doses of drug than control animals. Increased predisposition of drug abuse in adulthood has been shown in prenatally cocaine-exposed (Heyser et al., 1992; Rocha et al., 2002; Estelles et al., 2006), cannabinoid-exposed (Vela et al., 1998) and morphine-exposed offspring (Gagin et al., 1997) comparing to control animals. They showed increased drug-seeking behaviour in both self-administration test and condition place preference test (CPP).

The above mentioned studies suggest that prenatal drug exposure may induce cross-sensitization in adulthood regardless to the type of a drug. This would suggest that prenatal drug exposure induces general predisposition to drug addiction in adulthood. Although our previous study demonstrated (Šlamberová et al., 2012b), that there is a cross-effect between prenatal MA exposure and the challenge dose of cocaine and morphine in adulthood, prenatally MA-exposed rats do not display higher drug-seeking behaviour to these drugs as we expected. Therefore, we were interested, whether increased sensitivity induced by prenatal MA exposure would affect drug-seeking behaviour for related drugs administered in adulthood. Thus, the aim of the present study was to examine the MA-induced cross-sensitization to amphetamine (AMP), a drug with similar mechanisms of action as MA.

It has been shown that amphetamines activate the hypothalamo-pituitaryadrenal (HPA) axis and the increased level of corticosterone (CORT) has a neurodegenerative effect that leads to impaired cognitive functions (Deroche et al., 1992; Armstrong et al., 1993). Williams et al. (2003) demonstrated that MA administration during the neonatal period impairs spatial learning in an aversive non-swimming task and alters the adrenal response to a forced swim stressor, suggesting that the adrenal output during learning may contribute to the spatial learning deficits. Stress response is sex specific and may also be affected by psychostimulants administered either perinatally or in adulthood (Handa et al., 1994; Williams et al., 2003; Johnson and Yamamoto, 2010; Gralewicz et al., 
2011).A sex difference exists in the response of the HPA axis to stress, with females reacting more robustly than males. It is suggested that androgens act trans-synaptically within the hypothalamic paraventricular nucleus to inhibit HPA function, whereas estrogens cause a decrease in sensitivity to glucocorticoid receptor mediated negative feedback to enhance HPA function (Handa et al., 1994).

Therefore, the present study was aimed to evaluate possible behavioural and stress response changes as an effect of cross-sensitization to AMP by prenatal MA exposure with respect to gender of the exposed offspring.

\section{Methods}

All experimental procedures implemented in this report were reviewed and approved by the Institutional Animal Care and Use Committee and is in agreement with the Czech Government Requirements under the Policy of Humans Care of Laboratory Animals (No. 246/1992) and with subsequent regulations of the Ministry of Agriculture of the Czech Republic.

Prenatal and postnatal animal care

Adult female Wistar rats (250-300 g) were delivered by Anlab (Prague, the Czech Republic) from Charles River Laboratories International, Inc. Animals were housed 4-5 per cage and left undisturbed for a week in a temperature-controlled $\left(22-24^{\circ} \mathrm{C}\right)$ colony room with free access to food and water on a $12 \mathrm{~h}$ (light):12 $\mathrm{h}$ (dark) cycle with lights on at 06:00 a.m. The phase of females' estrous cycle was determined by vaginal lavage smears after one week of adaptation period. The smears were examined by light microscopy. Thereafter, female rats that were at the onset of estrous phase of the estrous cycle (Turner and Bagnara, 1976) were housed with sexually mature males overnight. There were always, one female and one male in a cage. The next morning females were smeared for the presence of sperm and returned to their previous home cages. This was counted as gestational day (GD) 1.

Dams were randomly assigned to MA-treated and saline-treated (controls). On GD 1 the daily injections started and continued till the day of delivery, which usually occurred on GD 22 (for details see Šlamberová et al., 2005). MA (SigmaAldrich ${ }^{\circledR}$ ) was injected subcutaneously (s.c.) in a dose of $5 \mathrm{mg} / \mathrm{kg}$, saline was injected s.c. at the same time in the same volume as MA.

The day of delivery was counted as postnatal day (PD) 0. On PD 21, pups were weaned and group-housed by sex. Animals were left undisturbed until adulthood. Always one male and one female rat (PD 70-90) per group was used in each experiment from each litter to avoid litter effects $(n=8)$. The rest of the animals were used in other experiments that will be presented as a part of another study. 
Open field test - Laboras

Laboras apparatus (Metris B.V., Netherlands) was used to test natural behaviour in adult male and female rats. Laboras is a fully automatic system for continuous behaviour recognition and tracking in small rodents (for details see Schutová et al., 2013). Challenge dose of AMP $(5 \mathrm{mg} / \mathrm{ml} / \mathrm{kg})$ or saline $(1 \mathrm{ml} / \mathrm{kg})$ was administered immediately prior to placing the animal to the Laboras cage to both of the prenatal exposure groups (prenatally MA-exposed and prenatally saline-exposed). Each animal was tested separately. Animal was placed to the centre of the plexiglass cage and the behaviour was monitored for 1 hour. After the recording, the animal's behaviour and its duration were analyzed within six 10-minute intervals. Following parameters were analyzed in all animals during the 1-h period of testing: the duration of locomotion [s], distance travelled [m], rearing (vertical exploratory behaviour) $[\mathrm{s}]$ and average velocity $[\mathrm{mm} / \mathrm{min}]$.

\section{Conditioned place preference (CPP)}

Another group of adult male rats were used to test AMP reward conditioning and how it is affected by prenatal MA exposure. CPP is one of the most widespread drug reward test (for review see Tzschentke, 1998). Based on Pavlovian conditioning principles, CPP reflects a preference for a context due to the contiguous association between the context and a drug-associated stimulus. It also presents important advantages, among which the possibility to reveal both reward and aversion, to test animals in a drug-free state and to allow simultaneous determination of locomotor activity (Fattore et al., 2005). The apparatus and the methodological procedure were in detail described in our previous study (Šlamberová et al., 2012a).

The conditioning for AMP $(5 \mathrm{mg} / \mathrm{ml} / \mathrm{kg}$ ) lasted for eight days. During the CPP test, animals were placed in the centre of the choice chamber with the doors opened and allowed free access to the entire apparatus for $15 \mathrm{~min}$. The time spent in each chamber and number of entries was recorded to assess individual preferences. The effect of adult (AMP) and prenatal (MA) exposure on tail temperature (measured by laser thermometer) and the number of faecal boluses produced during the sessions (stress sign).

\section{Morris water maze (MWM)}

Spatial memory was tested in the MWM on the $12^{\text {th }}$ day of experiment after 6 days of training (learning procedure) and 5 days of break. AMP $(5 \mathrm{mg} / \mathrm{ml} / \mathrm{kg})$ or saline $(1 \mathrm{ml} / \mathrm{kg})$ was administered during the entire time of experiment (11 days). During the learning period AMP was administered always after the training session, thus it would affect the memorizing process, but not the swimming performance of the animal (for detailed explanation see Macúchová et al., 2013).

Within the spatial memory test animals supposed to find the hidden platform within $60 \mathrm{~s}$ as they were trained during the learning sessions. The platform was 
located $1 \mathrm{~cm}$ under the water line at the same position as during the learning test. Each animal was subjected to 8 trials. The trials were tracked using a video-tracking system EthoVision XT7 (Noldus Information Technology, the Netherlands). The following parameters were analyzed: latency of platform acquisition [s], distance travelled $[\mathrm{cm}]$, search error $[\mathrm{m}]$, and the velocity of swimming $[\mathrm{cm} / \mathrm{s}]$.

In addition, search strategies (swimming pathways) of individual animal were manually analyzed after track acquisition on the day of spatial memory testing. The following search strategies were assigned (Schutová et al., 2009a): 1) thigmotaxis predominant swimming along the wall of the pool; 2) random search - swimming over the entire area of the pool in straight swims or in wide circular swims; 3 ) scanning - swimming over the central area of the pool; 4) search in an opposite quadrants - direct swim to an incorrect quadrant of the pool followed by loops and turns there; 5) search in a correct quadrant - direct swim to a correct quadrant of the pool followed by loops and turns there; 6) spatial search - direct swim path to the platform. Analysis of search strategies were aimed at a better understanding of differences in the process of learning in animals exposed to either MA prenatally or to AMP in adulthood.

\section{Corticosterone levels (EIA)}

Rats from the MWM test (administered by adult AMP or saline treatment for 11 days) were used for EIA (enzyme immunoassay) of CORT. Directly after the last swimming (during the second and third hour of the light period) rats were decapitated and the trunk blood was collected into pre-cooled tubes containing EDTA (ethylenediaminetetraacetic acid). Blood was centrifuged and plasma was immediately stored at $-70{ }^{\circ} \mathrm{C}$ until assayed. The amount of CORT in plasma was determined using a specific mouse/rat CORT competitive ElA kit (AC-14F1, Immunodiagnostic Systems Ltd., Boldon, UK) according to the manufacturer's instructions. Intra- and interassay coefficients of variations were $<6.6 \%$ and $<8.6 \%$, respectively. The sensitivity of the assay was $0.55 \mathrm{ng} / \mathrm{ml}$.

The same groups were divided as in the previous tests based on the prenatal drug exposure (prenatally MA- or saline-exposed), based on treatment in adulthood (saline- or AMP-treated), and based on the sex (males and females).

\section{Statistical analyses}

Data from each test were analyzed as follows.

Laboras. All behavioural activities were evaluated separately. Three-way ANOVA with repeated measure (between factors: prenatal drug, drug in adulthood, sex; within factors: 10-minute intervals) was used.

CPP test. Two-way ANOVA with repeated measure (between factors: prenatal exposure, chamber with or without challenge drug; within factor: time - before vs. after conditioning) was used to analyze differences in number of entries to chambers and total time spent in the specific chamber. 
MWM test. Three-way ANOVA with repeated measure (between factors: prenatal exposure, treatment in adulthood, sex; within factor: 8 trials) was used to analyze the data from the spatial memory testing. The $\chi^{2}$ test was used to analyze the occurrence of the search strategies.

CORT plasma levels. One-way ANOVA (between factor: sex) was used for basal levels of CORT.Three-way ANOVA (between factors: prenatal drug, drug in adulthood, sex) was used to test CORT level differences between groups after chronic AMP treatment in adulthood.

Bonferroni post-hoc test was used when appropriate. Differences were considered significant if $p<0.05$.

All statistical data in this report are presented as $[F(N-1, n-N)=x x . x x ; p<0.0 x]$, where $\mathrm{F}=$ test criterion of ANOVA, N-1 = degrees of freedom of groups, $\mathrm{n}-\mathrm{N}=$ degrees of freedom of individual subjects, $\mathrm{p}=$ probability level.

\section{Results}

Open field test - Laboras

Locomotion (Figures $1 \mathrm{~A}$ and $2 \mathrm{~A}$ ). In both sexes, AMP increased the locomotion $[F(1,96)=14.42 ; p<0.001]$. Further, the locomotion decreased with the time of the Laboras test dependently on the AMP treatment in adulthood $[F(5,480)=9.64$; $\mathrm{p}<0.0001]$.
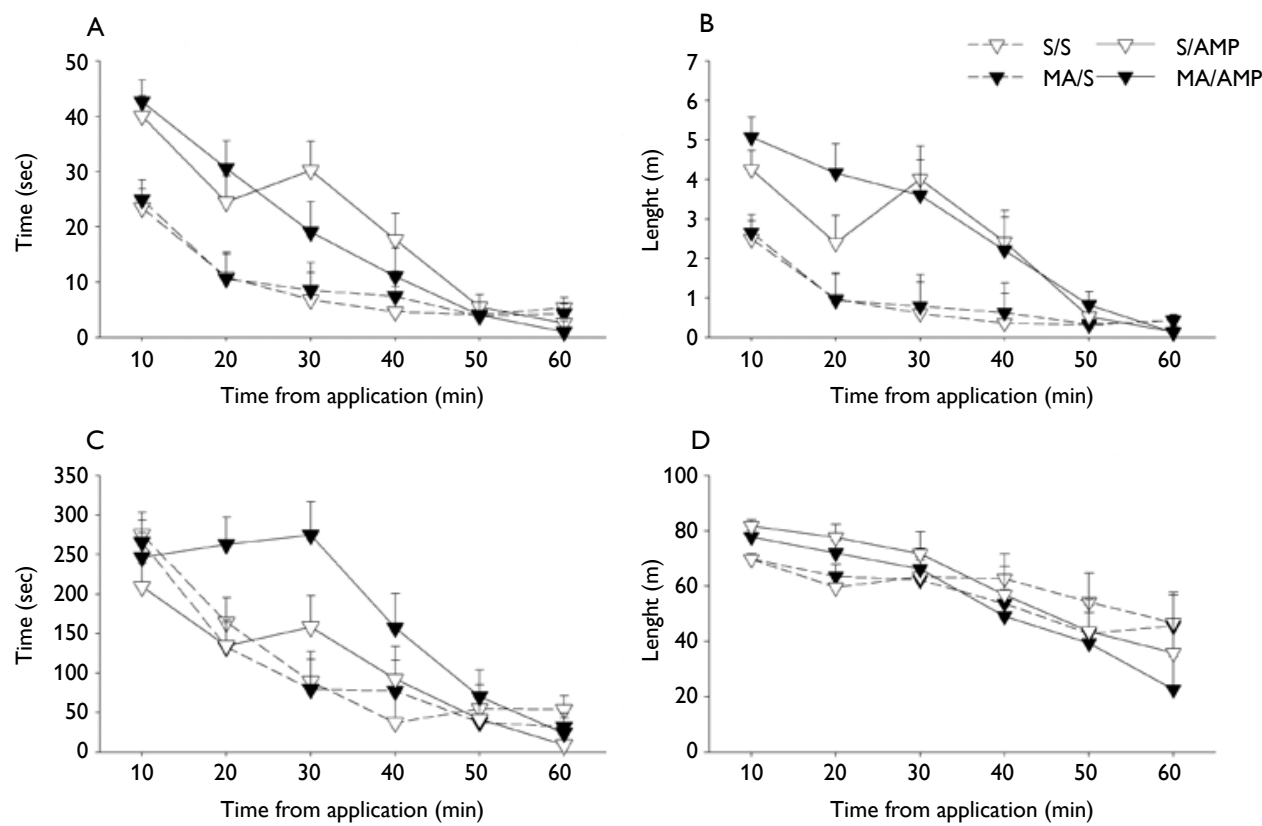

Figure 1 - The effect of prenatal MA exposure $(5 \mathrm{mg} / \mathrm{kg})$ and challenge dose of AMP $(5 \mathrm{mg} / \mathrm{kg})$ on locomotion $(A)$, distance $(B)$, rearing $(C)$, velocity $(D)$ tested in Laboras test in adult male rats. Values are means \pm SEM $(n=8)$. 

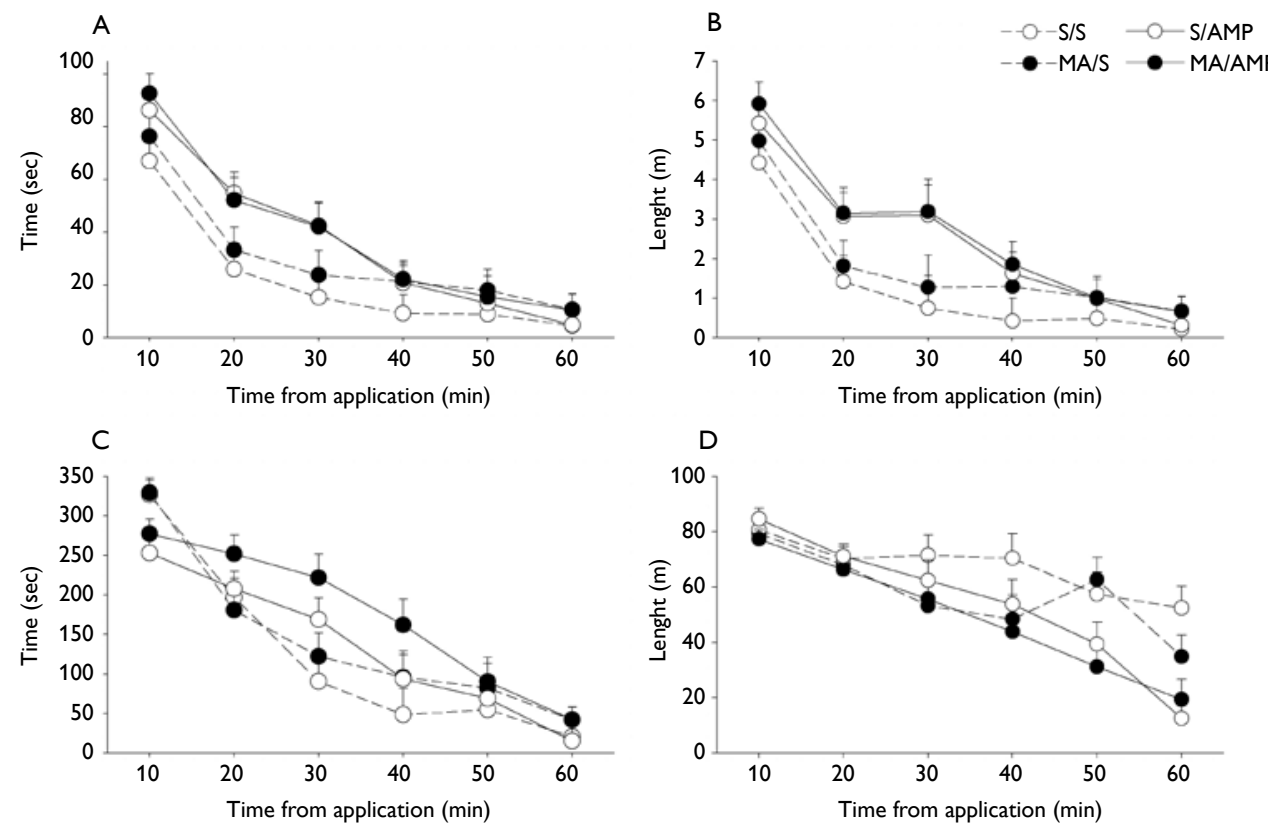

Figure 2 - The effect of prenatal MA exposure $(5 \mathrm{mg} / \mathrm{kg}$ ) and challenge dose of AMP (5 $\mathrm{mg} / \mathrm{kg})$ on locomotion $(A)$, distance $(B)$, rearing $(C)$, velocity $(D)$ tested in Laboras test in adult female rats. Values are means \pm SEM $(n=16)$.

Distance (Figures $1 \mathrm{~B}$ and $2 \mathrm{~B}$ ). In both sexes, AMP increased the distance travelled $[F(1,96)=18.03 ; p<0.0001]$. Furthermore, the distance travelled decreased with the time of the Laboras test dependently on the AMP treatment in adulthood $[F(5,480)=7.86 ; p<0.0001]$ and on the sex $[F(5,480)=2.79 ; p<0.05]$.

Rearing (Figures $1 C$ and $2 C$ ). In both sexes, AMP increased the rearing only in prenatally MA-exposed, but not in prenatally saline-exposed animals $[F(1,96)$ $=4.93 ; p<0.05]$. In addition, the rearing activity decreased with the time of the Laboras test dependently on the AMP treatment in adulthood $[F(5,480)=10.34$; $\mathrm{P}<0.0001]$.

Velocity (Figures 1D and 2D). In both sexes, the velocity decreased faster in animals treated in adulthood with AMP than saline-treated controls $[F(5,480)=6.54$; $p<0.0001]$.

\section{Conditioned place preference (CPP)}

As shown in Table 1, in adult male rats, AMP increased the number of entries to the chamber associated with the drug after conditioning regardless of the prenatal drug exposure $[F(1,28)=6.50 ; p<0.05]$. The time spent in the chamber associated with the drug was higher only in prenatally MA-exposed rats, but unchanged in prenatally saline-exposed rats $[F(2,28)=8.80 ; p<0.05]$. AMP increased the tail 


\section{Table 1 - Effect of amphetamine on measures in the conditioned place preference test in respect of the prenatal MA exposure and sex}

\begin{tabular}{lcccccccc}
\hline & \multicolumn{2}{c}{ Time } & \multicolumn{2}{c}{ Entries } & \multicolumn{2}{c}{ Tail temperature } & \multicolumn{2}{c}{ Boluses } \\
\cline { 2 - 9 } & control & MA & control & MA & control & MA & control & MA \\
\hline Males & $\uparrow$ & $\uparrow$ & - & $\uparrow$ & $\uparrow$ & - & $\uparrow$ & $\uparrow$ \\
Females & $\uparrow$ & $\uparrow$ & $\uparrow$ & $\uparrow$ & - & - & $\downarrow$ & $\downarrow$ \\
\hline
\end{tabular}

Arrows show AMP-induced increase $(\uparrow)$ or decrease $(\downarrow)$, respectively; dash means no difference induced by AMP treatment on the measures in the CPP test when compared to saline treatment in adulthood

temperature only in controls, but not in prenatally MA-exposed rats $[F(2,28)=$ $10.08 ; p<0.01]$, but increased the number of boluses dropped in both, prenatally MA- and saline-exposed male rats $[F(1,28)=44.15 ; p<0.0001]$.

In adult female rats (Table 1), AMP increased both, the number of entries to the chamber associated with the drug $[F(1,28)=3.44 ; p<0.05]$ and time spent in the chamber associated with the drug $[F(1,28)=54.62 ; p<0.0001]$. These effects of AMP were not affected by the prenatal drug exposure. AMP did not affect tail temperature in any of the prenatal groups. In contrast to males, AMP decreased the number of faecal boluses in both, prenatally MA- and saline-exposed female rats $[F(1,28)=8.41 ; p<0.01]$.

Morris water maze (MWM)

Latency (Figure 3A). AMP treatment in adulthood regardless of the prenatal drug exposure increased the latency to reach the hidden platform in females but not in males $[F(1,64)=6.38 ; p<0.05]$.

Distance (Figure 3B). AMP treatment in adulthood regardless of the prenatal drug exposure increased the swam distance to reach the hidden platform in females but not in males $[F(1,64)=8.73 ; p<0.01]$.

Search error (Figure 3C). AMP treatment in adulthood regardless of the prenatal drug exposure increased the search errors in females but not in males $[\mathrm{F}(1,64)=5.22 ; \mathrm{p}<0.05]$.

Velocity (Figure 3D). AMP treatment in adulthood regardless of the prenatal drug exposure increased the speed of swimming in males but not in females $[F(1,64)=6.66 ; p<0.05]$.

As a matter of used strategies during the spatial memory testing, males more often used a direct strategy (males 68.8\%, females $56.6 \% ; \chi^{2}=57.83 ; p<0.001$ ) or swimming in the quadrant with the hidden platform than females (males $7.0 \%$, females $\left.4.7 \% ; \chi^{2}=14.99 ; p<0.05\right)$. On the other hand the scanning strategy was more often used by females than by males (males $10.9 \%$, females $23.1 \% ; \chi^{2}=33.84$; $\mathrm{p}<0.0001$ ). Moreover, in females there was a difference in random strategy induced by AMP injection in adulthood: females with AMP used a random strategy more often than females (MA/AMP females $6.3 \%$, SA/AMP females $5 \%$, MA/SA females 

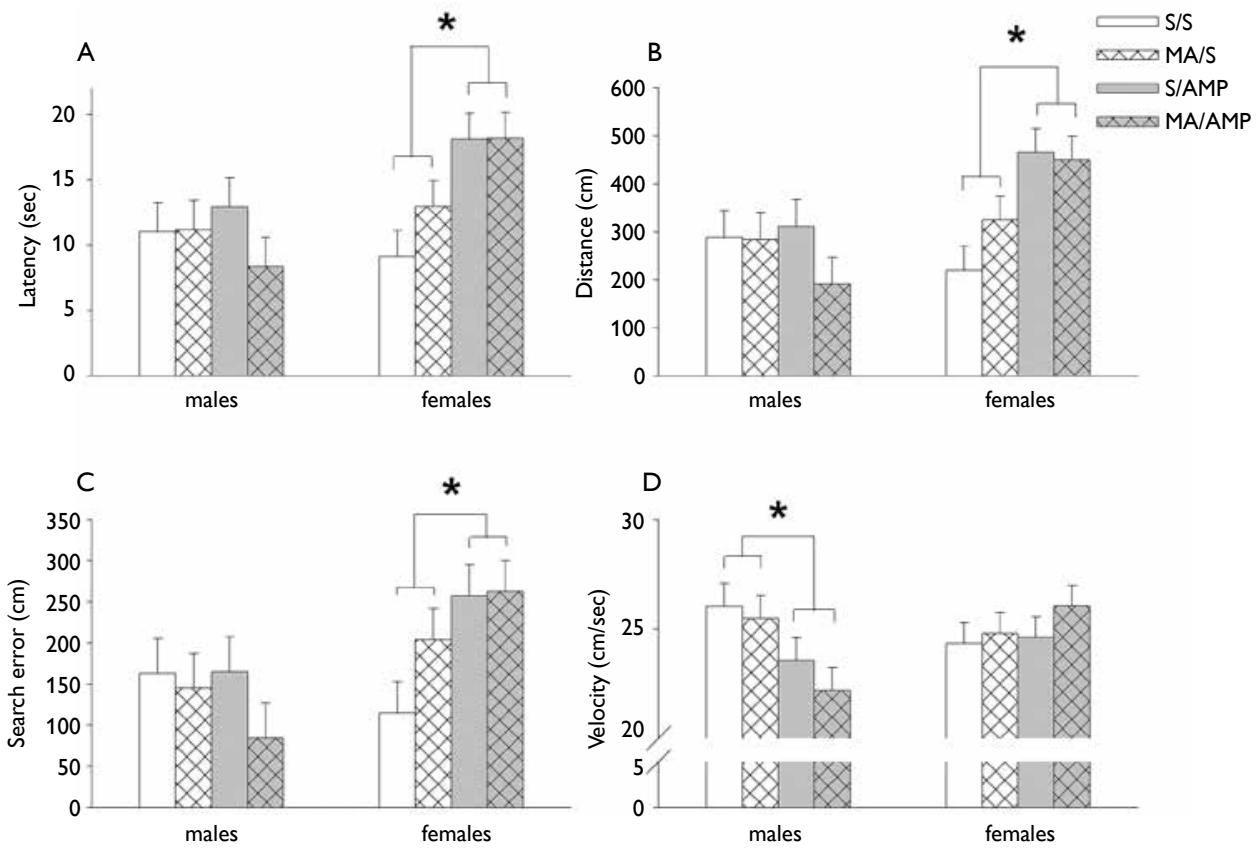

Figure 3 - The effect of prenatal MA exposure $(5 \mathrm{mg} / \mathrm{kg})$ and challenge dose of AMP (5 $\mathrm{mg} / \mathrm{kg})$ in MWM spatial memory test $\left(12^{\text {th }}\right.$ day) on latency $(A)$, distance $(B)$, search error $(C)$, velocity $(D)$ tested in adult male and female rats. Values are means \pm SEM ( $n=8$ in males and $n=16$ in females). ${ }^{*} p<0.05$ effect of AMP in adulthood:AMP (S/AMP and MA/AMP) vs. saline (S/S and MA/S).
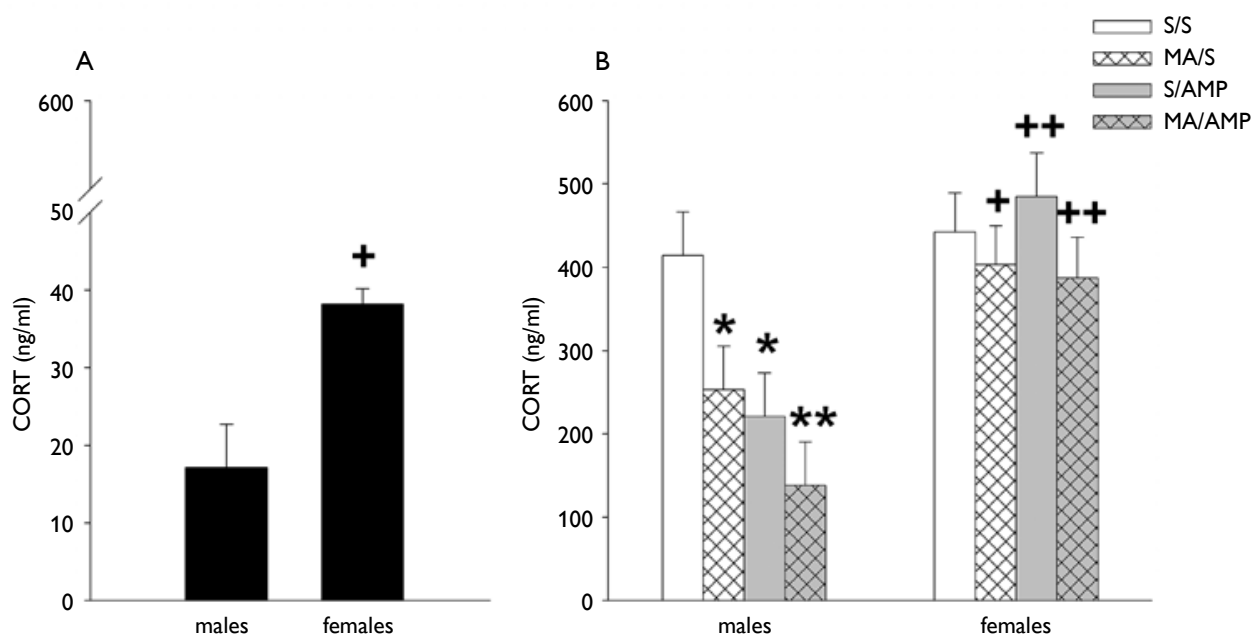

Figure 4 - CORT level showing sex differences in absolute controls (A) and in animals exposed prenatally to MA $(5 \mathrm{mg} / \mathrm{kg})$ and chronic AMP $(5 \mathrm{mg} / \mathrm{kg})$ treatment in adulthood that were tested in the MWM (B). Values are means \pm SEM $(n=8) .+p<0.05 ;++p<0.0001$ effect of sex: females $>$ males; ${ }^{*} p<0.05$, ${ }^{*} *_{p}<0.0001$ effect of drugs: $M A / S, S / A M P, M A / A M P<S / S$ in male rats.

Šlamberová R.; Macúchová E.; Nohejlová K.; Štofková A.; Jurčovičová J. 
$1.3 \%, \mathrm{SA} / \mathrm{SA}$ females $0 \%$ ), or than males regardless of the treatment (all groups $0 \%$; $\left.\chi^{2}=20.6 ; p<0.01\right)$.

\section{CORT plasma levels}

In absolute controls (animals that were not exposed to any, prenatal or adult, injections), there were sex differences in CORT levels; females displayed significantly higher CORT levels than males $(p<0.01)$ (Figure 4A).

When compared the effect of prenatal MA exposure and adult AMP treatment in both sexes (Figure 4B), our data showed that prenatal, as well as adult treatment decreased the CORT level only in males, but not in females $[F(1,61)=5.50$; $p<0.05]$. Males, prenatally saline-exposed and treated in adulthood with AMP (S/AMP) as well as both groups of prenatally MA-exposed groups of males (MA/S and MA/AMP) had lower CORT levels than males prenatally as well as in adulthood exposed to saline $(S / S)[F(1,61)=7.10 ; p<0.01]$. In addition, females had higher CORT levels than males in the following groups: prenatally saline-exposed, treated in adulthood with AMP (S/AMP) and in both groups prenatally MA-exposed (MA/S and MA/AMP) $[F(1,61)=23.42 ; p<0.0001]$.

\section{Discussion}

The present data demonstrate that adult AMP treatment may affect behaviour of adult rats, their memory and stress response in sex-specific manner and may be also affected by prenatal drug exposure.

In the Laboras test, the data showing no effect of prenatal MA exposure on behaviour in male or female rats is in agreement with our previous study examining adult rats prenatally exposed to MA in the open field test (Schutová et al., 2010; Hrubá et al., 2012). Unlike other studies (Heyser et al., 1992; Gagin et al., 1997; Rocha et al., 2002; Estelles et al., 2006) our data did not show any sensitization effect of prenatal MA exposure, except of exploratory activity. The reason may be that MA is not as potent drug to have such serious longlasting effect of cross-sensitization as cocaine or morphine. This finding is also in disagreement with our previous finding showing sensitization induced by prenatal MA exposure to MA challenge in adult male rats corresponding with dopamine levels in the nucleus accumbens (Bubeníková-Valešová et al., 2009). The possible explanation is that prenatal MA exposure induces the long-term sensitization only to the same drug received in adulthood, but does not induce cross-sensitization. In addition, the behavioural data showing increased locomotion, rearing as well as distance travelled induced by AMP treatment in adulthood in the Laboras test are in agreement with many studies demonstrating increased general locomotion activity in animals after administration of psychostimulants (Carey and Gui, 1997; Tzschentke and Schmidt, 1998; Carey and Damianopoulos, 2006; Ago et al., 2008).

In the CPP test, our data demonstrate that AMP induced increase in drug-seeking behaviour in adult male rats independently on prenatal MA exposure. The present 
results are consistent with our previous findings showing similar results after MA-induced conditioning in prenatally saline- and MA-exposed rats (Šlamberová et al., 2011). Both of these results are however in disagreement with studies showing increased predisposition of drug abuse in prenatally cocaine-exposed adult rats (Heyser et al., 1992; Rocha et al., 2002; Estelles et al., 2006). They showed increased drug-seeking behaviour in both "self-administration test" and the CPP. However note, that none of these studies examined drug-seeking behaviour in prenatally MA-exposed rats, but used model of prenatal cocaine exposure with conditioning to cocaine or morphine in adulthood. These inconsistencies suggest that cocaine is more potent drug for causing long-term addiction than MA. More studies are planned to test drug-seeking behaviour of prenatally MA-exposed rats also in the test of self-administration.

Also our previous study demonstrated that prenatal MA exposure may induce changes in drug-seeking behaviour tested in the CPP, even though these data showed that prenatal MA exposure induces rather tolerance than sensitization to cocaine (Šlamberová et al., 2012b). Because prenatal MA exposure did not induce any differences in the preference of MA or AMP, but did induce difference in the preference of cocaine, it is possible that the mechanism of action of all psychostimulant drugs may play a role in this effect. Even though all the drugs (MA, AMP, cocaine) are known to affect noradrenergic, dopaminergic and serotoninergic systems, the ratio of involvement of these neurotrasmitter systems do differ between these psychostimulant drugs. While MA and AMP seem to affect mostly the noradrenergic, then the dopaminergic and at minimum the serotoninergic system, cocaine seems to affect serotoninergic system the most (Fleckenstein et al., 2000; Rothman et al., 2001; Shoblock et al., 2003b). It should be noted that even though noradrenalin is released by AMP more from noradrenergic nerve terminals than dopamine from dopaminergic nerve terminals, the impact of the psychostimulant drugs on function is more accurately reflected based on the amount of the noradrenergic and dopaminergic innervations or relative abundance of the two neurotransmitters. Since dopamine is more abundant than noradrenalin, quantitatively the effect of amphetamine on behaviour mediated to a greater extent by the drug's effect on dopamine than on noradrenalin. However, because all the psychostimulant drugs affect all three neurotransmitters (noradrenalin, dopamine and serotonin) the ratio of the involvement of these neurotransmitters seems to be the most important. Thus, it is possible that the rate of involvement of these neurotransmitter systems in prenatal life with respect of the involvement of the other system(s) in adulthood may play a role in these findings.

In the MWM, the results did not show any effect of prenatal MA exposure on spatial learning abilities of male or female rats, respectively, while AMP treatment in adulthood induced changes in spatial memory tested in the MWM in a sex-specific manner. Animals with AMP treatment in adulthood showed decreased performance in the test, they had increased the latencies, the distances travelled, and the search 
errors when compared to saline-treated control group. Other studies (Schutová et al., 2008; Cao et al., 2013; Macúchová et al., 2013), did not find any effect of MA treatment in adulthood on the ability of the animals to memorize the location of the platform. This discrepancy between effects of these two related psychostimulants suggests differences in mechanism of their influence of the neurochemical pathways in the CNS during spatial navigation task. For instance, Shoblock et al. $(2003 a, b)$ reported AMP to be more potent than MA at affecting the working memory and releasing of dopamine in the prefrontal cortex.

As mentioned before, females were shown to be more sensitive to the effect of AMP treatment than males (Camp and Robinson, 1988; Forgie and Stewart, 1993; Bisagno et al., 2003; Páleníček et al., 2005; Milesi-Halle et al., 2007). Moreover, it seems that male rats were able to recall the location of the platform more effectively than females, as they displayed faster learning. This effect was mostly apparent in AMP-treated animals; males swam shorter distances and had shorter latencies than females. We also found some sex differences in the strategies of swimming used in the test. Specifically, females swam more often in the opposite distant from platform quadrant than males, while males swam directly to the platform than females. These findings are in agreement with studies showing sexual differences in the cognitive abilities of females and males. In human studies, men tend to be better at spatial orientation, while women at verbal activities (Jarvik, 1975). These differences seem to be due to organizational and activation effect of gonadal hormones, particularly oestrogen and testosterone (Sherwin, 1997).

We demonstrated sex differences in the basal as well as drug-induced CORT level differences after MWM testing. The finding that females displayed higher levels of CORT are in agreement with studies of others showing more robust stress response and sensitivity of the HPA axis in female than in male rats (Handa et al., 1994). In addition, the MWM task has been shown to have an aversive component to it (Morris, 1984) and this has been supported by findings that there is adrenal activation and release of CORT following training in the MWM (Roozendaal et al., 1996; Akirav et al., 2001). Further, Williams et al. (2003) demonstrated that there is a decrease of CORT level after MWM testing induced by neonatal MA treatment only in male, but not female rats, which is in agreement with our present results. Moreover, it is possible that the CORT levels in MA/S, S/AMP and MA/AMP females is increased chronically and might be responsible for the impairing effects on spatial memory, while in $S / S$ females we see only acute CORT increase induced by swimming in the MWM (Chu et al., 2003; Lee et al., 2014).

In conclusion, the present results demonstrate that there are no sex differences in behaviour after acute treatment of AMP in adulthood, while adult females seem to be more sensitive to chronic AMP treatment than males. We did not see prenatally MA-induced sensitization to AMP that would suggest long-term sensitization as we expected. The only exception seems to be the effect of prenatal and adult drug exposure on vertical exploratory activity, suggesting increased 
stereotypy behaviour of prenatally MA-exposed rats treated in adulthood with AMP. Our data showed sex differences in CORT levels and decreased effect of prenatal MA exposure and AMP treatment in adulthood in male but not female rats. Furthermore, the higher CORT levels in MA-exposed rats and AMP-treated female rats may account for their worsened MWM performance in comparison to male rats. These findings raise attention and pose many questions that will be investigated in future studies.

\section{References}

Acuff-Smith, K. D., Schilling, M. A., Fisher, J. E., Vorhees, C.V. (1996) Stage-specific effects of prenatal d-methamphetamine exposure on behavioral and eye development in rats. Neurotoxicol. Teratol. 18, 199-215.

Ago, Y., Arikawa, S., Yata, M., Yano, K., Abe, M., Takuma, K., Matsuda, T. (2008) Antidepressant-like effects of the glucocorticoid receptor antagonist RU-43044 are associated with changes in prefrontal dopamine in mouse models of depression. Neuropharmacology 55, 1355-1363.

Akirav, I., Sandi, C., Richter-Levin, G. (2001) Differential activation of hippocampus and amygdala following spatial learning under stress. Eur. J. Neurosci. 14, 719-725.

Armstrong, J. N., Mclntyre, D. C., Neubort, S., Sloviter, R. S. (1993) Learning and memory after adrenalectomy-induced hippocampal dentate granule cell degeneration in the rat. Hippocampus 3 , 359-371.

Bartoletti, M., Gaiardi, M., Gubellini, C., Bacchi, A., Babbini, M. (1985) Cross-sensitization to the excitatory effect of morphine in post-dependent rats. Neuropharmacology 24, 889-893.

Bernášková, K., Matějovská, I., Šlamberová, R. (2011) Postnatal challenge dose of methamphetamine amplifies anticonvulsant effects of prenatal methamphetamine exposure on epileptiform activity induced by electrical stimulation in adult male rats. Exp. Neurol. 229, 282-287.

Bisagno, V., Ferguson, D., Luine, V. N. (2003) Chronic D-amphetamine induces sexually dimorphic effects on locomotion, recognition memory, and brain monoamines. Pharmacol. Biochem. Behav. 74, 859-867.

Bubeníková-Valešová,V., Kačer, P., Syslová, K., Rambousek, L., Janovský, M., Schutová, B., Hrubá, L., Šlamberová, R. (2009) Prenatal methamphetamine exposure affects the mesolimbic dopaminergic system and behavior in adult offspring. Int. J. Dev. Neurosci. 27, 525-530.

Camp, D. M., Robinson, T. E. (1988) Susceptibility to sensitization. II. The influence of gonadal hormones on enduring changes in brain monoamines and behavior produced by the repeated administration of D-amphetamine or restraint stress. Behav. Brain Res. 30, 69-88.

Cao, G., Zhu, J., Zhong, Q., Shi, C., Dang, Y., Han, W., Liu, X., Xu, M., Chen, T. (2013) Distinct roles of methamphetamine in modulating spatial memory consolidation, retrieval, reconsolidation and the accompanying changes of ERK and CREB activation in hippocampus and prefrontal cortex. Neuropharmacology 67, 144-154.

Carey, R., Gui, J. (1997) A simple and reliable method for the positive identification of Pavlovian conditioned cocaine effects in open-field behavior. J. Neurosci. Methods 73, 1-8.

Carey, R. J., Damianopoulos, E. N. (2006) Cocaine conditioning and sensitization: the habituation factor. Pharmacol. Biochem. Behav. 84, 128-133.

Cho, D. H., Lyu, H. M., Lee, H. B., Kim, P.Y., Chin, K. (1991) Behavioral teratogenicity of methamphetamine. J. Toxicol. Sci. 16, 37-49 (Suppl. 1).

Chu, Y., Mouat, M. F., Harris, R. B., Coffield, J. A., Grider, A. (2003) Water maze performance and changes in serum corticosterone levels in zinc-deprived and pair-fed rats. Physiol. Behav. 78, 569-578.

Šlamberová R.; Macúchová E.; Nohejlová K.; Štofková A.; Jurčovičová J. 
Deroche, V., Piazza, P.V., Casolini, P., Maccari, S., Le Moal, M., Simon, H. (1992) Stress-induced sensitization to amphetamine and morphine psychomotor effects depend on stress-induced corticosterone secretion. Brain Res. 598, 343-348.

Estelles, J., Rodriguez-Arias, M., Maldonado, C., Aguilar, M. A., Minarro, J. (2006) Gestational exposure to cocaine alters cocaine reward. Behav. Pharmacol. 17, 509-515.

Fattore, L., Deiana, S., Spano, S. M., Cossu, G., Fadda, P., Scherma, M., Fratta, W. (2005) Endocannabinoid system and opioid addiction: behavioural aspects. Pharmacol. Biochem. Behav. 81, 343-359.

Fleckenstein, A. E., Gibb, J.W., Hanson, G. R. (2000) Differential effects of stimulants on monoaminergic transporters: pharmacological consequences and implications for neurotoxicity. Eur. J. Pharmacol. 406, $1-13$.

Forgie, M. L., Stewart, J. (1993) Sex differences in amphetamine-induced locomotor activity in adult rats: role of testosterone exposure in the neonatal period. Pharmacol. Biochem. Behav. 46, 637-645.

Gagin, R., Kook, N., Cohen, E., Shavit, Y. (1997) Prenatal morphine enhances morphine-conditioned place preference in adult rats. Pharmacol. Biochem. Behav. 58, 525-528.

Gralewicz, S., Lutz, P., Swiercz, R., Grzelinska, Z., Wiaderna, D. (2011) Neuroendocrine and behavioral response to amphetamine challenge after exposure to an organophosphorus pesticide. Int. J. Occup. Med. Environ. Health 24, 283-291.

Handa, R. J., Burgess, L. H., Kerr, J. E., O’Keefe, J.A. (1994) Gonadal steroid hormone receptors and sex differences in the hypothalamo-pituitary-adrenal axis. Horm. Behav. 28, 464-476.

He, S., Grasing, K. (2004) Chronic opiate treatment enhances both cocaine-reinforced and cocaine-seeking behaviors following opiate withdrawal. Drug Alcohol Depend. 75, 215-221.

Heyser, C. J., Goodwin, G. A., Moody, C. A., Spear, L. P. (1992) Prenatal cocaine exposure attenuates cocaineinduced odor preference in infant rats. Pharmacol. Biochem. Behav. 42, 169-173.

Hrubá, L., Schutová, B., Šlamberová, R. (2012) Sex differences in anxiety-like behavior and locomotor activity following prenatal and postnatal methamphetamine exposure in adult rats. Physiol. Behav. 105, 364-370.

Jarvik, L. F. (1975) Human intelligence: sex differences. Acta Genet. Med. Gemellol. (Roma) 24, 189-211.

Johnson, B. N., Yamamoto, B. K. (2010) Chronic stress enhances the corticosterone response and neurotoxicity to +3,4-methylenedioxymethamphetamine (MDMA): the role of ambient temperature. J. Pharmacol. Exp. Ther. 335, 180-189.

Kitaichi, K., Morishita, Y., Doi, Y., Ueyama, J., Matsushima, M., Zhao, Y. L., Takagi, K., Hasegawa, T. (2003) Increased plasma concentration and brain penetration of methamphetamine in behaviorally sensitized rats. Eur. J. Pharmacol. 464, 39-48.

Lee, B., Sur, B., Shim, I., Lee, H., Hahm, D. H. (2014) Baicalin improves chronic corticosterone-induced learning and memory deficits via the enhancement of impaired hippocampal brain-derived neurotrophic factor and cAMP response element-binding protein expression in the rat. J. Nat. Med. 68, 132-143.

Macúchová, E., Nohejlová-Deykun, K., Šlamberová, R. (2013) Effect of methamphetamine on cognitive functions of adult female rats prenatally exposed to the same drug. Physiol. Res. 62, S89-S98.

Malanga, C. J., Kosofsky, B. E. (2003) Does drug abuse beget drug abuse? Behavioral analysis of addiction liability in animal models of prenatal drug exposure. Brain Res. Dev. Brain Res. 147, 47-57.

Martin, J. C., Martin, D. C., Radow, B., Sigman, G. (1976) Growth, development and activity in rat offspring following maternal drug exposure. Exp. Aging Res. 2, 235-251.

Marwick, C. (2000) NIDA seeking data on effect of fetal exposure to methamphetamine. JAMA 283, 2225-2226.

Matějovská, I., Bernášková, K., Šlamberová, R. (2014) Effect of prenatal methamphetamine exposure and challenge dose of the same drug in adulthood on epileptiform activity induced by electrical stimulation in female rats. Neuroscience 257, 130-138. 
Milesi-Halle, A., McMillan, D. E., Laurenzana, E. M., Byrnes-Blake, K. A., Owens, S. M. (2007) Sex differences in $(+)$-amphetamine- and $(+)$-methamphetamine-induced behavioral response in male and female Sprague-Dawley rats. Pharmacol. Biochem. Behav. 86, 140-149.

Morris, R. (1984) Developments of a water-maze procedure for studying spatial learning in the rat. J. Neurosci. Methods 11, 47-60.

Páleníček, T., Votava, M., Bubeníková,V., Horáček, J. (2005) Increased sensitivity to the acute effects of MDMA ("ecstasy") in female rats. Physiol. Behav. 86, 546-553.

Polanecký,V., Šejda, J., Studničková, B. (1996) Prevalence study of serious substance abusers in the Czech Republic. Cent. Eur.J. Public Health 4, 176-184.

Rocha, B. A., Mead, A. N., Kosofsky, B. E. (2002) Increased vulnerability to self-administer cocaine in mice prenatally exposed to cocaine. Psychopharmacology (Berl.) 163, 221-229.

Roozendaal, B., Bohus, B., McGaugh, J. L. (1996) Dose-dependent suppression of adrenocortical activity with metyrapone: effects on emotion and memory. Psychoneuroendocrinology 21, 681-693.

Rothman, R. B., Baumann, M. H., Dersch, C. M., Romero, D.V., Rice, K. C., Carroll, F. I., Partilla, J. S. (2001) Amphetamine-type central nervous system stimulants release norepinephrine more potently than they release dopamine and serotonin. Synapse 39, 32-41.

Schutová, B., Hrubá, L., Pometlová, M., Deykun, K., Šlamberová, R. (2008) Impact of methamphetamine administered prenatally and in adulthood on cognitive functions of male rats tested in Morris water maze. Prague Med. Rep. 109, 62-70.

Schutová, B., Hrubá, L., Pometlová, M., Deykun, K., Šlamberová, R. (2009a) Cognitive functions and drug sensitivity in adult male rats prenatally exposed to methamphetamine. Physiol. Res. 58, 741-750.

Schutová, B., Hrubá, L., Pometlová, M., Šlamberová, R. (2009b) Impact of prenatal and acute methamphetamine exposure on behaviour of adult male rats. Prague Med. Rep. 110, 67-78.

Schutová, B., Hrubá, L., Pometlová, M., Rokyta, R., Šlamberová, R. (2010) Responsiveness to methamphetamine in adulthood is altered by prenatal exposure in rats. Physiol. Behav. 99, 381-387.

Schutová, B., Hrubá, L., Rokyta, R., Šlamberová, R. (2013) Gender differences in behavioral changes elicited by prenatal methamphetamine exposure and application of the same drug in adulthood. Dev. Psychobiol. $\mathbf{5 5}$, 232-242.

Šejda, J., Studničková, B., Polanecký, V. (1998) Trends in the incidence of problematic drug addicts in the Czech Republic, 1995-1996. Cent. Eur. J. Public Health 6, 18-24.

Sherwin, B. B. (1997) Estrogen effects on cognition in menopausal women. Neurology 48, S21-S26.

Shoblock, J. R., Maisonneuve, I. M., Glick, S. D. (2003a) Differences between d-methamphetamine and $\mathrm{d}$-amphetamine in rats: working memory, tolerance, and extinction. Psychopharmacology (Berl.) 170, 150-156.

Shoblock, J. R., Sullivan, E. B., Maisonneuve, I. M., Glick, S. D. (2003b) Neurochemical and behavioral differences between d-methamphetamine and d-amphetamine in rats. Psychopharmacology (Berl.) 165, 359-369.

Šlamberová, R., Charousová, P., Pometlová, M. (2005) Methamphetamine administration during gestation impairs maternal behavior. Dev. Psychobiol. 46, 57-65.

Šlamberová, R., Pometlová, M., Charousová, P. (2006) Postnatal development of rat pups is altered by prenatal methamphetamine exposure. Prog. Neuropsychopharmacol. Biol. Psychiatry 30, 82-88.

Šlamberová, R., Schutová, B., Matějovská, I., Bernášková, K., Rokyta, R. (2009) Effects of a single postnatal methamphetamine administration on NMDA-induced seizures are sex- and prenatal exposure-specific. Naunyn Schmiedebergs Arch. Pharmacol. 380, 109-114.

Šlamberová, R., Yamamotová, A., Schutová, B., Hrubá, L., Pometlová, M. (2011) Impact of prenatal methamphetamine exposure on the sensitivity to the same drug in adult male rats. Prague Med. Rep. $112,102-114$.

Šlamberová R.; Macúchová E.; Nohejlová K.; Štofková A.; Jurčovičová J. 
Šlamberová, R., Pometlová, M., Schutová, B., Hrubá, L., Macúchová, E., Nová, E., Rokyta, R. (2012a) Do prenatally methamphetamine-exposed adult male rats display general predisposition to drug abuse in the conditioned place preference test? Physiol. Res. 61, S129-S138 (Suppl. 2).

Šlamberová, R., Yamamotová, A., Pometlová, M., Schutová, B., Hrubá, L., Nohejlová-Deykun, K., Nová, E., Macúchová, E. (2012b) Does prenatal methamphetamine exposure induce cross-sensitization to cocaine and morphine in adult male rats? Prague Med. Rep. 113, 189-205.

Turner, C. D., Bagnara, J.T. (1976) Endocrinology of the ovary. In: General Endocrinology, eds. Turner, C. D., Bagnara, J.T., pp. 450-495, W. B. Saunders Company, Philadelphia.

Tzschentke, T. M. (1998) Measuring reward with the conditioned place preference paradigm: a comprehensive review of drug effects, recent progress and new issues. Prog. Neurobiol. 56, 613-672.

Tzschentke, T. M., Schmidt, W. J. (1998) The development of cocaine-induced behavioral sensitization is affected by discrete quinolinic acid lesions of the prelimbic medial prefrontal cortex. Brain Res. 795, 71-76.

Valvassori, S. S., Frey, B. N., Martins, M. R., Reus, G. Z., Schimidtz, F., Inacio, C. G., Kapczinski, F., Quevedo, J. (2007) Sensitization and cross-sensitization after chronic treatment with methylphenidate in adolescent Wistar rats. Behav. Pharmacol. 18, 205-212.

Vela, G., Martin, S., Garcia-Gil, L., Crespo, J. A., Ruiz-Gayo, M., Javier Fernandez-Ruiz, J., Garcia-Lecumberri, C., Pelaprat, D., Fuentes, J. A., Ramos, J. A., Ambrosio, E. (1998) Maternal exposure to delta9tetrahydrocannabinol facilitates morphine self-administration behavior and changes regional binding to central mu opioid receptors in adult offspring female rats. Brain Res. 807, 101-109.

Williams, M. T., Blankenmeyer, T. L., Schaefer, T. L., Brown, C. A., Gudelsky, G. A., Vorhees, C.V. (2003) Long-term effects of neonatal methamphetamine exposure in rats on spatial learning in the Barnes maze and on cliff avoidance, corticosterone release, and neurotoxicity in adulthood. Brain Res. Dev. Brain Res. 147, 163-175.

Won, L., Bubula, N., McCoy, H., Heller, A. (2001) Methamphetamine concentrations in fetal and maternal brain following prenatal exposure. Neurotoxicol. Teratol. 23, 349-354.

Yamamotová, A., Šlamberová, R. (2012) Behavioral and antinociceptive effects of different psychostimulant drugs in prenatally methamphetamine-exposed rats. Physiol. Res. 61, S139-S147 (Suppl. 2). 